\title{
Mechanical and physical characterization of hydroxyapatite/alumina biocomposites produced by the powder metallurgy route for biomedical applications
}

\author{
Caracterização mecânica e física de \\ biocompósitos de hidroxiapatita / alumina \\ produzidos pela rota de metalurgia do \\ pó para aplicações biomédicas
}

Mayara Ribeiro Masseli ${ }^{1}$, Bruna Horta Bastos Kuffner ${ }^{1}$, Lucas Victor Benjamim Vasconcelos ${ }^{1}$, Gilbert Silva ${ }^{1}$, Daniela Sachs ${ }^{1}$

\footnotetext{
${ }^{1}$ Federal University of Itajubá, Department of Physics and Chemistry, B P S Avenue, 1303, CEP: 37500-903, Minas Gerais, Itajubá, Brazil.

e-mail: vasconcelos.lvb@unifei.edu.br
}

\begin{abstract}
The hydroxyapatite calcium phosphate based ceramic (Hap) is widely used for bone repair, as it is a biocompatible biomaterial and because it has osteoconductive and osteoinductive properties. However, the low mechanical strength of Hap may limit its applicability. Thus, the present work aims to improve the mechanical properties of Hap, associating it with alumina $\left(\mathrm{Al}_{2} \mathrm{O}_{3}\right)$, using the powder metallurgy technique, which consists in the milling of the precursor powders in a planetary ball mill, uniaxial pressing and sintering. The microstructure and mechanical strength of the sintered samples were evaluated using density, microhardness, compressive strength and wettability tests. It was concluded that the use of $\mathrm{Al}_{2} \mathrm{O}_{3}$ in the composite improves the mechanical properties of Hap, while decreases its hydrophilic potential. Thus, the composition with $40 \%$ Hap / $60 \% \mathrm{Al}_{2} \mathrm{O}_{3}$ was considered the best for biomedical applications.
\end{abstract}

Keywords: Hydroxyapatite; Alumina; Powder Metallurgy; Microstructure; Mechanical Strength.

\section{RESUMO}

A cerâmica à base de fosfato de cálcio hidroxiapatita (Hap) é muito utilizada para reparos ósseos por ser um biomaterial biocompatível e apresentar propriedades osteocondutoras e osteoindutoras. No entanto, a baixa resistência mecânica da Hap pode limitar sua aplicabilidade. Assim, o presente trabalho tem como objetivo melhorar as propriedades mecânicas da Hap, associando-a à alumina $\left(\mathrm{Al}_{2} \mathrm{O}_{3}\right)$, pela técnica de metalurgia do pó, que consiste na moagem dos pós precursores em moinho planetário, prensagem uniaxial e sinterização. A microestrutura e a resistência mecânica das amostras sinterizadas foram avaliadas através dos testes de densidade, microdureza, resistência à compressão e molhabilidade. Concluiu-se que o uso de $\mathrm{Al}_{2} \mathrm{O}_{3}$ no compósito melhora as propriedades mecânicas da Hap, enquanto diminui seu potencial hidrofílico. Assim, a composição com $40 \%$ de Hap / $60 \%$ de $\mathrm{Al}_{2} \mathrm{O}_{3}$ foi considerada a melhor para aplicações biomédicas.

Palavras-chave: Hidroxiapatita; Alumina, Metalurgia do Pó, Microestrutura, Resistência Mecânica.

\section{INTRODUCTION}

Bone defects greater than the critical size are difficult to cure and can occur as result of trauma, tumors, and other bone lesions. The objective of developing biomaterials is producing biomedical devices that help to improve human life, and they constitute a vast field of scientific research. In this context, there is a high demand for implants and bone substitutes that do not cause rejection, while inducing osteoconductivity with desirable mechanical properties $[1,2]$. 
Synthetic hydroxyapatite (Hap), $\mathrm{Ca}_{10}\left(\mathrm{PO}_{4}\right)_{6}(\mathrm{OH})_{2}$, has been widely used as a bone substitute, as it binds to bone tissue and also demonstrates osteoconductive behavior. Hap is a calcium phosphate based ceramic, with a chemical composition similar to the inorganic component of bones and teeth. In fact, it is widely used as a bone substitute due to its biocompatibility, bioactivity and osteoconductivity properties [3-7]. Although Hap is biocompatible and bioactive, high loads limit its applications, because of its inherent low mechanical properties (such as low toughness, fracture and wear resistance), which limit its application in the human body [8-10].

The addition of metal oxides to the hydroxyapatite improves the structural and morphological characteristics and, therefore, increases its mechanical properties [11, 12]. Thus, to improve the mechanical properties of Hap, other materials such, as alumina, zirconia, titanium, silica, zinc oxide and some carbon-based materials may be associated with the development of ceramic biocomposites. In fact, alumina $\left(\mathrm{Al}_{2} \mathrm{O}_{3}\right)$, when compared to Hap, has high abrasion and corrosion resistance, hydrophilicity, and has been used in the manufacture of hip prosthesis since 1970 [13]. However, $\mathrm{Al}_{2} \mathrm{O}_{3}$ is bioinert and does not induce osteoconduction [1416].

Authors such as $[17,18]$ consider osseointegration an interaction between clinical, histological and perspective, being the biological processes of osseointegration still limited. In addition, both authors consider six critical factors to obtain good osseointegration: Correct material, finishing, design, implant loading conditions, host bone quality and surgical technique applied. In terms of materials engineering, the four first conditions are those that control the obtainment of a good osseointegration.

The powder metallurgy (PM) is a technique that allows the production of many composites, with metallic, ceramic or polymeric matrix. In comparison with the traditional melting process, one PM advantage that overcomes is the fact that uses low temperature processing. It prevents the formation of undesirable phases during the heat treatment. In addition, it gives better mechanical results due homogeneous distribution of the reinforcing particles in the matrix. Other advantages of PM include lower cost for large-scale production, the ability to create workpieces in different shapes and virtually no material wastage. The process includes obtaining the powders, compaction in a matrix and sintering over a controlled atmosphere. In the case of sintering, the powders acquire mechanical strength through atomic diffusion [19-22].

Based on the data described, the present study aimed to develop a ceramic biocomposite with Hap / $\mathrm{Al}_{2} \mathrm{O}_{3}$, produced through the powder metallurgy route, with osteonductivity of Hap and properly mechanical properties of $\mathrm{Al}_{2} \mathrm{O}_{3}$.

\section{EXPERIMENTAL}

The Hap was acquired from the company $\mathrm{JHS}^{\circledR}$, and the $\mathrm{Al}_{2} \mathrm{O}_{3}$ powder from the company Alcoa ${ }^{\circledR}$. For the composites milling process, it was used a planetary ball mill Noah-Nuoya ${ }^{\circledR}$ NQM 0.2 L, with rotation speed of $150 \mathrm{rpm}$, ball to powder mass ratio of 3:1 and time of 1 hour. The milling vases presented volume of 200 $\mathrm{ml}$. The milling spheres presented 3 different diameter sizes: $21 \mathrm{~mm}, 13 \mathrm{~mm}$ and $8 \mathrm{~mm}$, being the mass ratio of 3:1 calculated according to these diameters. In addition, both vases and spheres were confectioned in zirconia. Table 1 describes the proportion of the powders used in the composites production. It was defined according to other studies that produced hydroxyapatite / calcium silicate composites [23].

Table 1: Composites compositions.

\begin{tabular}{c|c|c}
\hline Composition & Hap & $\mathrm{Al}_{2} \mathrm{O}_{3}$ \\
\hline 1 & $100 \%$ & $0 \%$ \\
\hline 2 & $80 \%$ & $20 \%$ \\
\hline 3 & $60 \%$ & $40 \%$ \\
\hline 4 & $40 \%$ & $60 \%$ \\
\hline 5 & $20 \%$ & $80 \%$ \\
\hline 6 & $0 \%$ & $100 \%$ \\
\hline
\end{tabular}

After the milling process, the samples were uniaxially pressed with pressure of $1 \mathrm{tf}$ during 30 seconds. In sequence, the samples were sintered in a vacuum oven up to $1200^{\circ} \mathrm{C}$ at a $10^{\circ} \mathrm{C} / \mathrm{min}$ rate, maintained for 1 
hour and then naturally cooled inside the oven. The composites were characterized using a Carl Zeiss EVO® MA15 scanning electron microscope. Secondary electron (SE) mode analyzed the particles size variation, as well as the morphology of the forerunner and composite powders. Energy dispersive X-ray mode (EDX) evaluated the chemical composition of the composites. Compressive strength test determined the samples stress x strain curves, being then found the Young's modulus from these. For the procedure, an Instron ${ }^{\circledR} 8001$ testing machine was used, under a controlled load condition and an off rate constant cross-head speed of 2 $\mathrm{mm} / \mathrm{min}$. Archimedes principle evaluated the density, and the wettability determined the angle formed between the sessile drop and the material contact surface. The equipment Krüss model FM40Mk2 EasyDro goniometer tested the composites hydrophilic potential. This variable evaluates the ability of a fluid (in the case of body fluids) to spread over the material surface. The data presents mean \pm standard error mean (SEM) and analyses of variance (ANOVA), in order to determine the statistical significance among compositions, following Newman-Keuls post hoc analysis. Results with $P<0.05$ were considered statistically significant. Graph PadPrism 4.0 software analyzed the data (GraphPad Software Inc., San Diego, CA, USA).

\section{RESULTS AND DISCUSSION}

Figure 1 shows the photomicrographs of compound 5, with $20 \%$ Hap / $80 \% \mathrm{Al}_{2} \mathrm{O}_{3}$, analyzed through SEM. In Figure 1a, the backscattered electron detector (BSD) mode allows us to identify the sample surface composition. The lighter regions of the image represent the hydroxyapatite, while the darker regions represent the aluminum oxide. The Hap is well dispersed all over the surface of $\mathrm{Al}_{2} \mathrm{O}_{3}$ matrix, showing that the sample presented good densification. This composition has the highest percentage of $\mathrm{Al}_{2} \mathrm{O}_{3}$ among all samples, and consequently, the best mechanical properties. Figure $1 \mathrm{~b}$, which has a better contrast through SEM/EDS, exhibits the dispersion of the Hap over the $\mathrm{Al}_{2} \mathrm{O}_{3}$ matrix. The chemical elements of Hap and $\mathrm{Al}_{2} \mathrm{O}_{3}$ are individually represented by different colors. The oxygen corresponds to the blue color in Figure 1c, and the aluminum, the red color in Figure 1d. Both represent the composition of the $\mathrm{Al}_{2} \mathrm{O}_{3}$. Calcium corresponds to yellow in Figure 1d, and the phosphorous to green in Figure 1f, both component of Hap. From Figure 1c to Figure 1f, Hap spread along the $\mathrm{Al}_{2} \mathrm{O}_{3}$ matrix, without the presence of undesirable phases. It indicates that the powder metallurgy process was efficient to produce this composite. Starting from the powders obtainment, the Hap and $\mathrm{Al}_{2} \mathrm{O}_{3}$ were properly homogenized. In compacting process, the pressed powders did not present defects. Furthermore, both temperature and time of sintering were appropriate to produce $\mathrm{Al}_{2} \mathrm{O}_{3}$ composites with good densification.

Figure 2 presents the sintered densities, Vickers microhardness and Young's modulus of the compositions 1 to 6 . By observing the density values after sintering (Figure 2a), from composition 1 to 2, the density values decreased $9.86 \%$. For composition 2 to 3, the density decreased $3.53 \%$. For composition 3 to 4 , the density decreased $0.58 \%$. For composition 4 to 5 , the density value slightly increased $3.11 \%$. Finally, for composition 5 to 6 , the density increases $1.04 \%$. This inversion happens due to the density of the pure $\mathrm{Al}_{2} \mathrm{O}_{3}$ sintered at $1200{ }^{\circ} \mathrm{C}\left(2.49 \mathrm{~g} / \mathrm{cm}^{3}\right)$, being $9.12 \%$ lower than the pure Hap sintered at $1200{ }^{\circ} \mathrm{C}\left(2.74 \mathrm{~g} / \mathrm{cm}^{3}\right)$. With this, as the percentage of $\mathrm{Al}_{2} \mathrm{O}_{3}$ of the samples increases, the density of the compositions also increases, until an inversion occurs due the tendency of the compositions to approach the density of the pure $\mathrm{Al}_{2} \mathrm{O}_{3}$. With this inversion, the values are considered very close to each other, due to the fact that the density of both forerunner materials (compositions 1 and 6) are very similar. The literature [24, 25] indicates a density of $2.45 \mathrm{~g} / \mathrm{cm}^{3}$ to the $\mathrm{Al}_{2} \mathrm{O}_{3}$ and $3.02 \mathrm{~g} / \mathrm{cm}^{3}$ to the Hap, both sintered at $1200{ }^{\circ} \mathrm{C}$. Comparing this research results, the $\mathrm{Al}_{2} \mathrm{O}_{3}$ presented a value only $1.92 \%$ smaller than the literature, and the Hap a value $9.27 \%$ smaller. Although the Hap presented a higher value than the $\mathrm{Al}_{2} \mathrm{O}_{3}$, it is considered close.

Figures $2 \mathrm{~b}$ (Vickers microhardness) and 2c (Young's modulus) confirm that, as the $\mathrm{Al}_{2} \mathrm{O}_{3}$ increases, the values of microhardness and Young's modulus also increase, as expected. It happens due to the fact that the $\mathrm{Al}_{2} \mathrm{O}_{3}$ presents high hardness and mechanical strength, which does not happen with the Hap [26]. The different proportions caused an increment of $7.76 \%$ in the microhardness and $28.96 \%$ in the Young's modulus from composition 1 to composition 2. From composition 2 to 3, it was of $24.95 \%$ in the microhardness and $51 \%$ in the Young's modulus. From composition 3 to 4 , the increment was of $43.11 \%$ in the microhardness and $16.64 \%$ in the Young's modulus. From composition 4 to 5, it was of $29.89 \%$ in the microhardness and $13.36 \%$ in the Young's modulus, and from composition 5 to 6 , it was of $3.02 \%$ in the microhardness and $7.58 \%$ in the Young's modulus. In general, there was an average increment of $70 \%$ for both microhardness and Young's modulus from composition 1 to 6 (73.22 \% for microhardness and $76.76 \%$ for Young's modulus), which are the pure compositions. This indicates that the $\mathrm{Al}_{2} \mathrm{O}_{3}$ presents an average mechanical resistance $70 \%$ higher than the Hap. Factors such as applied tension during pressing and the presence of defects inside the samples before and after sintering, affect the final density and mechanical properties of mate- 

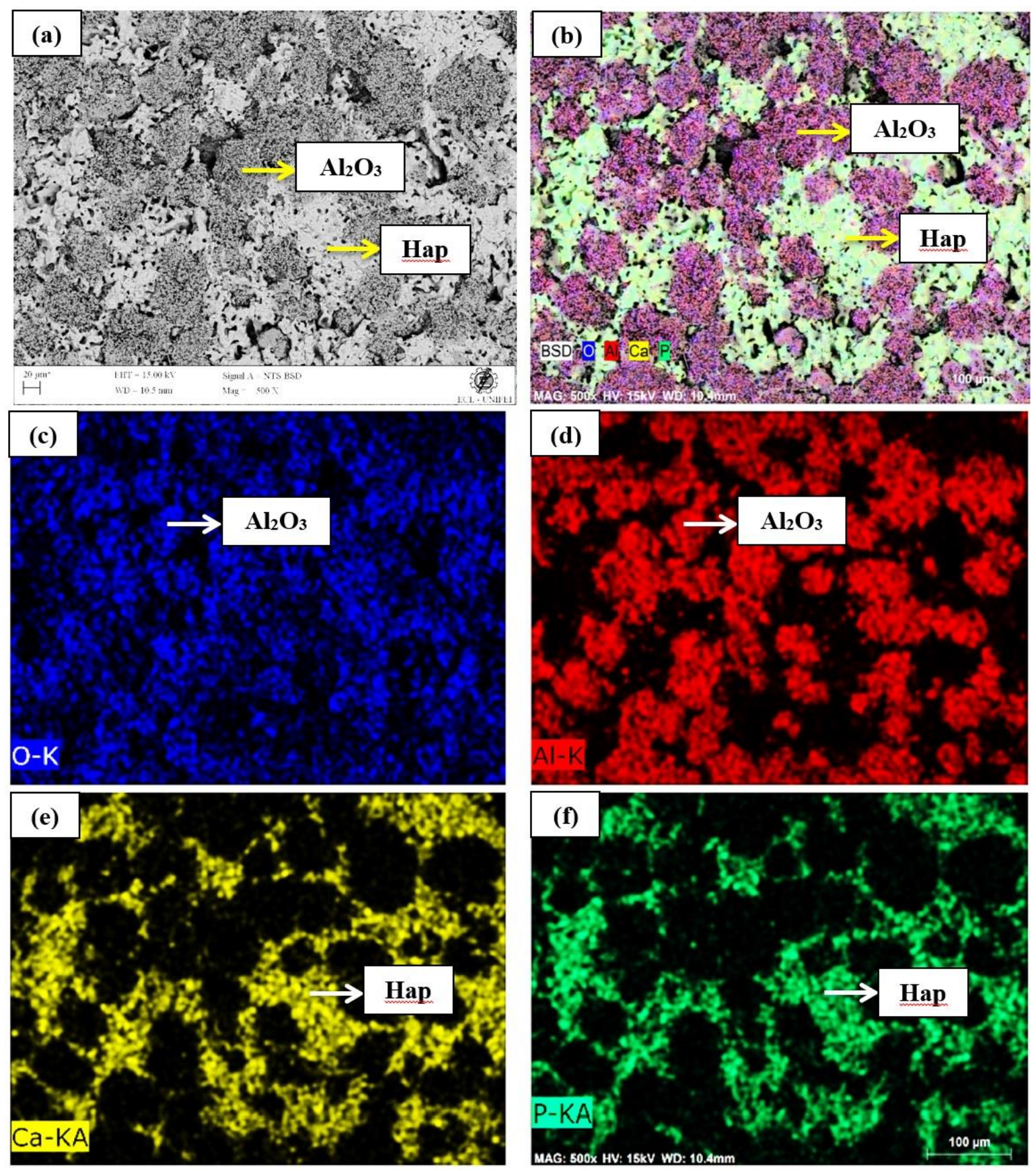

rials produced by powder metallurgy.

Figure 1: Photomicrographs of composition 5 showing (a) The surface of the sintered sample by BSD mode (b) The dispersion of the Hap over the $\mathrm{Al}_{2} \mathrm{O}_{3}$ matrix (c) The oxygen element from $\mathrm{Al}_{2} \mathrm{O}_{3}$ (d) The aluminum element from $\mathrm{Al}_{2} \mathrm{O}_{3}$ (e) The calcium element from Hap (f) The phosphor element from Hap. 

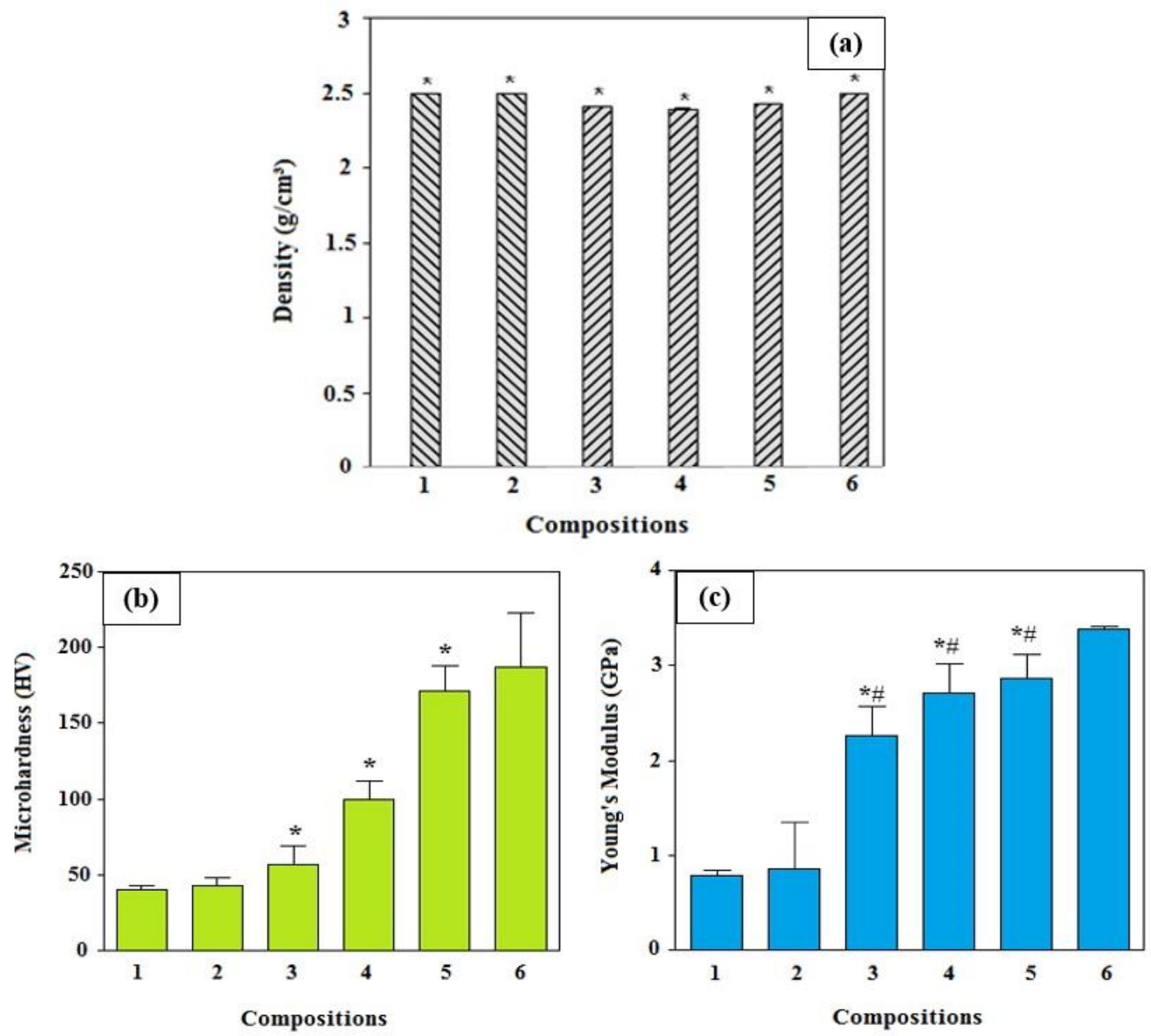

Figure 2: Physical and mechanical properties of the compositions 1 to 6 (a) Sintered densities (b) Vickers microhardness (c) Young's modulus. $* P<0.05$ when compared to green compositions.

Table 2 shows the contact angle, aspect of sessile drop and porosity of each composition. As it can be seen, as the content of $\mathrm{Al}_{2} \mathrm{O}_{3}$ of the compositions increases, the contact angle also increases. From composition 1 to composition 2, it was observed an increase of $26.46^{\circ}$ in the contact angle of the sessile drop; from composition 2 to 3 , an increase of $26.28^{\circ}$; from composition 3 to 4 , an increase of $4.22^{\circ}$; from composition 4 to 5 , an increase of $15.74^{\circ}$; and finally, from composition 5 to 6 , an increase of $13.4^{\circ}$. It is possible to verify an increase of $86.1^{\circ}$ in the contact angle of the sessile drop from compositions 1 to 6 . This is explained by the fact that the Hap is much more osteoconductive and osteoinductive than the $\mathrm{Al}_{2} \mathrm{O}_{3}$. The spreadability of the sessile drop reflects it, since the more biocompatible with the bone is the material the higher is the hydrophilic behavior. The literature indicates that hydrophilic materials present a contact angle below $90^{\circ}$ and hydrophobic materials above $90^{\circ}$ [27]. With this, it was possible to attest that the compositions with $\mathrm{Al}_{2} \mathrm{O}_{3}$ content over $60 \%$ (compositions 5 and 6) presented hydrophobic behavior, implying in a material with low potential to be used in bone grafts. 
Table 2: Contact angle, aspect of the sessile drop and porosity of each composition. The data are expressed by the mean \pm standard error

\begin{tabular}{|c|c|c|c|}
\hline Composition & Contact angle $\left({ }^{\circ}\right)$ & Aspect of sessile drops & Porosity (\%) \\
\hline 1 & $26.040 \pm 3.587$ & & $0.372 \pm 0.010$ \\
\hline 2 & $52.500 \pm 4.179$ & & $0.0338 \pm 0.028$ \\
\hline 3 & $78.780 \pm 6.931$ & & $0.337 \pm 0.016$ \\
\hline 4 & $83.000 \pm 7.992$ & & $0.336 \pm 0.017$ \\
\hline 5 & $98.740 \pm 4.144$ & & $0.394 \pm 0.046$ \\
\hline 6 & $112.140 \pm 7.74$ & & $0.346 \pm 0.013$ \\
\hline
\end{tabular}

The analysis of the density, mechanical strength (microhardness and Young's modulus) and contact angle, pointed that while the $\mathrm{Al}_{2} \mathrm{O}_{3}$ content of the compositions increased, the mechanical strength also increased, but density values remained stable. However, at the same proportion that the mechanical strength of

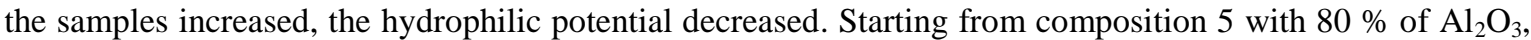
the composite started to demonstrate hydrophobic behavior. Based in these results, it was determined that the ideal composition for the composite $\mathrm{Hap} / \mathrm{Al}_{2} \mathrm{O}_{3}$ was composition 4, which presented the highest mechanical strength among all samples and contact angle of $83^{\circ}$ (which is still classified as hydrophilic material).

\section{CONCLUSIONS}

By analyzing the results obtained in this study, it was possible to conclude that:

- As the $\mathrm{Al}_{2} \mathrm{O}_{3}$ content increases, the mechanical strength of the composites also increases, but the biological potential to be used in biomedical devices starts to decrease from composition 5 .

- The best condition to produce $\mathrm{Hap} / \mathrm{Al}_{2} \mathrm{O}_{3}$ composites was the condition with $40 \% \mathrm{Hap} / 60 \% \mathrm{Al}_{2} \mathrm{O}_{3}$ (composition 4).

\section{AKNOWLEDGMENTS}

The authors would like to thank the CAPES, the technicians Jonas Mendes and Marcos Cirilo dos Santos (Federal University of Itajubá, Minas Gerais, Brazil) for their technical assistance and the company Alcoa from Poços de Caldas - MG, for the $\mathrm{Al}_{2} \mathrm{O}_{3}$ donation.

\section{BIBLIOGRAPHY}

[1] HAUGEN, H.J., LYNGSTADAA, S.P.S., ROSSI, F., et al., "Bone grafts: which is the ideal biomaterial? Journal of Clinical Periodontology. v. 46, n. S21, pp. 92-102, Jun. 2019. 
[2] JEONG, J., KIM, J.H., SHIM, J.H., et al., "Bioactive calcium phosphate materials and applications in bone regeneration" Biomaterials Research. v. 23, n. 1, p. 1-11, 14 Jan. 2019

[3] DE AZA, P.N., PENÃ, J.I., LUKLINSKA, Z.B., et al., "Bioeutectic ${ }^{\circledR}$ Ceramics for Biomedical Application Obtained by Laser Floating Zone Method. In vivo Evaluation" Materials. v. 7, n. 4, pp. 23952410, 25 Mar. 2014.

[4] TAN, L., YU, X., WAN, P., et al., "Biodegradable Materials for Bone Repairs: A Review "Journal of Materials Science \& Technology. v. 29, n. 6, pp. 503-513, 1 Jun. 2013

[5] SZCZEŚ, A., HOŁYSZ, L., CHIBOWSKI, E., "Synthesis of hydroxyapatite for biomedical applications" Advances in Colloid and Interface Science, v. 249, pp. 321-330, 1 Nov. 2017.

[6] SIDDIQUI, H.A., PICKERING, K.L., MUCALO, M.R., "Review on the Use of HydroxyapatiteCarbonaceous Structure Composites in Bone Replacement Materials for Strengthening Purposes", Materials (Basel). v. 11, n. 10, pp. 1813, 24 Sep. 2018.

[7] SHI, C., GAO, J., WANG, M., et al., "Functional hydroxyapatite bioceramics with excellent osteoconductivity and stern-interface induced antibacterial ability", Biomaterials Science, v. 4, n. 4, pp. 699710, Apr. 2016.

[8] SPRIO, S., TAMPIERI, A., CELOTTI, G., et al., "Development of hydroxyapatite/calcium silicate composites addressed to the design of load-bearing bone scaffolds", Journal of the Mechanical Behavior of Biomedical Materials, v. 2, n. 2, pp. 147-155, Apr. 2009.

[9] ZHOU, H., LEE, J., "Nanoscale hydroxyapatite particles for bone tissue engineering", Acta Biomaterialia. v. 7, n. 7, pp. 2769-2781, Jul. 2011.

[10] ZAKARIA, S.M., ZEIN, S.H.S., OTHMAN, M.R., et al., "Nanophase Hydroxyapatite as a biomaterial in advanced hard tissue engineering: A review" Tissue Engineering Part B: Reviews, v. 19, n. 5, pp. 431-441, Oct. 2013.

[11] HUANG, Y., HUANG, W., SUN, L., et al., "Phase Transition from $\alpha$-TCP into $\beta$-TCP in TCP/HA Composites", International Journal of Applied Ceramic Technology, v. 7, n. 2, pp. 184-188, 1 Mar. 2010.

[12] MOHAMED, K.R., BEHEREI, H.H., EL BASSYOUNI, G.T., et al., "Fabrication and mechanical evaluation of hydroxyapatite/oxide nano-composite materials", Materials Science and Engineering: C, v. 33, n. 7, pp. 4126-4132, Oct. 2013.

[13] BEN-NISSAN, B., CHOI, A.H., CORDINGLEY, R., Bioceramics and Their Clinical Applications, Ed Kokubo Cambridge: Woodhead Publishing, 2008.

[14] STEA, S., SAVARINO, L., TONIET, A., et al., "Microradiographic and histochemical evaluation of mineralization inhibition at the bone-alumina interface" Biomaterials, v. 13, n. 10, pp. 664-667, Jan. 1992.

[15] OKADA, Y., KOBAYASHI, M., NEO, M., et al., "Ultrastructure of the interface between alumina bead composite and bone" Journal of Biomedical Materials Research, v. 49, n. 1, pp. 106-111, 1 Jan. 2000.

[16] TARIQUE, A.A-M., TSURU, K., MARUTA, M., et al., "In vitro osteoconductivity evaluation of alumina treated hydrothermally in CaCl2 solution" Journal of the Ceramics Society of Japan, v. 118, n. 1378, pp. 512-515, 1 Jun. 2010.

[17] HUANG, Y. S., MCGOWAN, T., LEE, R., et al., "Dental Implants: Biomaterial properties influencing osseointegration" Comp. Biomater. v.3, n.7, pp. 444-466, 2017.

[18] ALBREKTSSON, T.C., JEMT, T., et al., "Is marginal bone loss around oral implants the result of a provoked foreign body reaction?", Clinical Implant Dentristy and Related Research, v. 16, n. 2, pp. 155-165, 1 Apr. 2014.

[19] BOLZONI, L., RUIZ-NAVAS, E.M., GORDO, E.. "Quantifying the properties of low-cost powder metallurgy titanium alloys", Materials Science and Engineering: A, v. 687, pp. 47-53, 27 Feb. 2017.

[20] KUFFNER, B.H.B., DIOGO, W.S., AMANCIO, D.A., et al., "Evaluation of the milling efficiency increase of AISI 52100 steel using niobium carbide addition through high energy ball milling", REM: Revista Escola De Minas, v. 68, n. 3, pp. 295-300, 1 Jul. 2015.

[21] SURYANARAYANA, C., "Mechanical alloying and milling", Progress in Materials Science, v. 46, n. $1-2$, p. 1-184, Jan. 2001.

[22] KUFFNER, B.H.B., FACCI, A.D., SACHS, D., et al., "Study of the microstructure and mechanical properties of beta tricalcium phosphate-based composites with alumina addition produced by powder metallurgy.” REM - International Engineering Journal, v. 70, n. 4, pp. 459-464, Oct. 2017.

[23] SHIRAZI, F.S., MEHRALI, M., OSHKOUR, A.A., et al., "Mechanical and physical properties of calci- 
um silicate/alumina composite for biomedical engineering applications" Journal of the Mechanical Behaviour of Biomedical Materials, v.168 n.30, 2014.

[24] GREGOROVÁ, H., PABST, W., NECINA, V., et al., "Young's modulus evolution during heating, resintering and cooling of partially sintered alumina ceramics", Journal of the European Ceramic Society, v. 39, n. 5, pp. 1893-1899, 1 May 2019.

[25] CHEN, P.Y., WANG, S.F., CHEIN, R.R., et al., "Evolution of the microstructural and mechanical properties of hydroxyapatite bioceramics with varying sintering temperature", Ceramics International v. 45, n. 13, pp. 16226-16233, 1 Sep. 2019.

[26] TEIXEIRA, L.H.P., SANTOS, C., DAGUANO, J.K.M.F., et al., "Sinterização e propriedades mecânicas do compósito Y-TZP/Al 2O 3" Cerâmica, v. 53, n. 327, pp. 227-233, Jul. 2007.

[27] IOST, C.A.R., RAETANO, C.G., “Tensão superficial dinâmica e ângulo de contato de soluções aquosas com surfatantes em superfícies artificiais e naturais”, Engenharia Agrícola Jaboticabal, v. 30, n. 4, pp. 670680, Jul. 2010.

\section{ORCID}

Bruna Horta Bastos Kuffner

Mayara Ribeiro Masseli

Lucas Victor Benjamim Vasconcelos

Gilbert Silva

Daniela Sachs https://orcid.org/0000-0003-3306-5102

https://orcid.org/0000-0003-2098-1881

https://orcid.org/0000-0001-5133-2310

https://orcid.org/0000-0002-6636-4013

https://orcid.org/0000-0002-3767-2455 